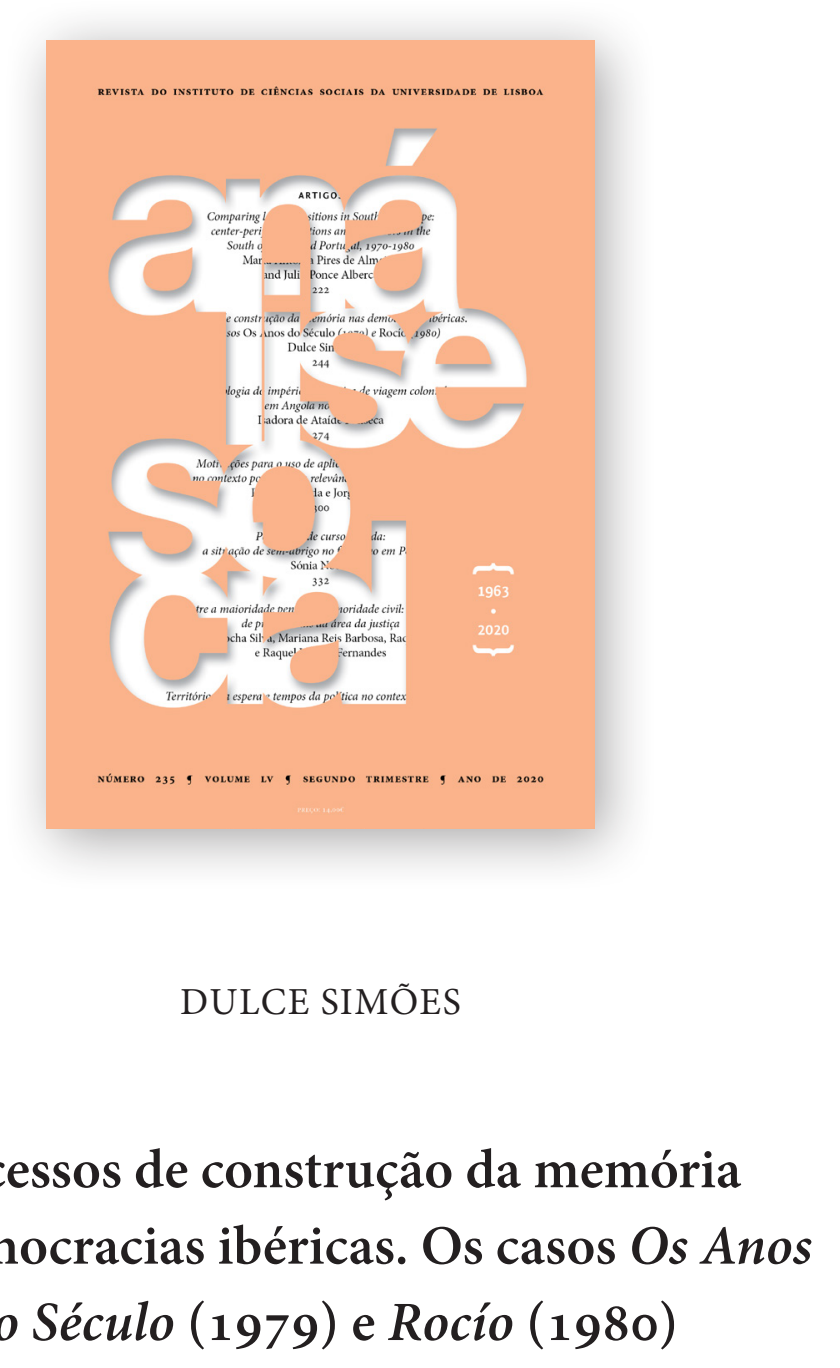

\title{
Processos de construção da memória nas democracias ibéricas. Os casos Os Anos do Século (1979) e Rocío (1980)
}

Análise Social, LV (2. $\left.{ }^{\circ}\right), 2020$ (n. $\left.{ }^{\circ} 235\right)$, pp. 244-273 https://doi.org/10.31447/ASO0032573.2020235.02 ISSN ONLINE 2182-2999 
Análise Social, 235, LV $\left(2 .^{\circ}\right), 2020,244-273$

Processos de construção da memória nas democracias ibéricas. Os casos Os Anos do Século (1979) e Rocío (1980). Os processos de democratização das sociedades ibéricas abriram inicialmente uma etapa de libertação da memória do passado ditatorial para adotarem posteriormente estratégias de "reconciliação", acompanhadas do silenciamento da guerra civil espanhola (1936-1939) e da guerra colonial portuguesa (1961-1974). Neste texto questiono as políticas da memória desenvolvidas na primeira década da transição para a democracia, em Portugal e Espanha, a partir dos casos Os Anos do Século (1979) e Rocío (1980), como meios de reprodução de memórias que afrontaram os poderes políticos, eclesiásticos e militares, desencadearam processos judiciais, mobilizaram os órgãos de comunicação social e convocaram a opinião pública para um debate sobre o direito à liberdade de expressão.

PALAVRAS-CHAVE: políticas da memória; transição democrática; guerra civil de Espanha (1936-1939); guerra colonial (1961-1974).

The processes of democratization of the Iberian societies: the cases Os Anos do Século (1979) and Rocío (1980). The processes of democratization of the Iberian societies initially opened a stage of liberation from the memory of the dictatorial past to later adopt strategies of "reconciliation", accompanied by the silencing of the Spanish Civil War (1936-1939) and the Portuguese Colonial War (1961-1974). In this text I question the politics of memory developed in the first decade of the transition to democracy, in Portugal and Spain, from the cases Os Anos do Século (1979) and Rocío (1980), as means of reproducing memories that defied the political, ecclesiastical and military powers, launched legal proceedings, mobilized the media and called public opinion to a debate on the right to freedom of expression.

KEYWORDS: politics of memory; democratic transition; Spanish Civil War; Portuguese Colonial War (1961-1974).

https://doi.org/10.31447/ASO0032573.2020235.02 


\title{
Processos de construção da memória nas democracias ibéricas. Os casos Os Anos do Século (1979) \\ e Rocío (1980) ${ }^{1}$
}

\author{
INTRODUÇÃO
}

A memória, onde cresce a história, que por sua vez a alimenta, procura salvar o passado para servir o presente e o futuro. Devemos trabalhar de forma a que a memória coletiva sirva para a libertação e não para a servidão dos homens [Le Goff, 1989, p. 50].

Os processos de democratização das sociedades ibéricas, iniciados na década de 70, abriram inicialmente uma etapa de libertação da memória do passado ditatorial para adotarem posteriormente estratégias de "reconciliação", acompanhadas do silenciamento da guerra civil espanhola (1936-1939)² e da guerra colonial portuguesa (1961-1974). ${ }^{3}$ A transição democrática em Espa-

1 Este trabalho é financiado por fundos nacionais através da FCT - Fundação para a Ciência e a Tecnologia, I. P., no âmbito da Norma Transitória DL 57/2016/CP1453/CTO047.

2 A guerra civil espanhola foi consequência do golpe militar de 18 de julho de 1936 contra o governo democraticamente eleito da II Republica. O conflito provocou o assassinato de 130199 republicanos e o desaparecimento de mais de 114199, segundo os números recolhidos pelas associações de recuperação da memória histórica enviados ao juiz Baltazar Garzón a 22 de setembro de 2008, para figurarem no "Auto de instrução pelas vítimas da guerra civil de Espanha" (Proc. Ordinário 53/2008, de 18 de novembro de 2008). O exílio político provocado pelo conflito produziu um êxodo de uma magnitude e alcance sem precedentes na história de Espanha, que segundo a Asociación de Descendientes del Exilio Español atingiu mais de 350 ooo pessoas.

3 A guerra colonial opôs os movimentos de libertação africanos ao domínio colonial português. Os 13 anos de conflito em Angola, Guiné e Moçambique originaram mais de $8000 \rightarrow$ 
nha resultou de um "pacto de silêncio" em que os dirigentes políticos acordaram esquecer o passado, "ya que ello era considerado incompatible con el objectivo de establecer en España un régimen democrático estable y duradero" (Aguilar Fernández, 2008, p. 26). No caso português, o processo de democratização procedeu de um golpe militar e de uma revolução política e social "que reunia todas as condições para produzir uma rutura clara com o passado ditatorial, não apenas na sua dimensão política, mas também nas suas dimensões sociais, económicas e culturais" (Loff, 2015, p. 26). Nas últimas quatro décadas, as memórias destas guerras converteram-se num intenso campo de batalha pela hegemonia sobre o passado, com múltiplas políticas da memória $^{4}$ a confluírem no espaço público modeladas por publicações, exposições e filmes divulgados nos meios de comunicação social, que permitiram alargar o espaço de debate e enunciação. A incessante reconstrução e silenciamento a que têm sido submetidas por parte de instituições do Estado, movimentos sociais, grupos sociopolíticos e indivíduos, atesta a persistência de um passado que não passa $a^{5}$ no campo da memória coletiva e da sua inscrição na memória pública das sociedades.

Maurice Halbwachs (1950) ensinou-nos que toda a memória é coletiva, preservada nos grupos sociais e construída a partir do presente da rememoração. As lembranças são assim influenciadas por novos conhecimentos, por experiências que se sobrepõem, e selecionadas a partir de um conjunto potencialmente infinito de memórias possíveis, pela relevância para os indivíduos que recordam e pelo contributo para a construção de identidades (Fentress e Wickham, 1994). A persistência da memória num dado grupo social resulta da força da sua identidade face à sociedade, da certeza depositada pelos seus membros na sua versão do passado e do papel da comemoração na transmissão e conservação da memória coletiva. A diferentes versões do passado preservadas nos grupos opõem-se versões oficiais e hegemónicas, legitimadas por discursos retóricos articulados por elites políticas e intelectuais que raramente

\footnotetext{
$\rightarrow$ mortes nos militares portugueses e cerca de 30000 feridos, desconhecendo-se o número de vítimas entre a população civil e os guerrilheiros africanos. A guerra foi também uma das causas da forte vaga emigratória que conduziu mais de um milhão de portugueses para fora do país (Cardina, 2017, p. 82).

4 As políticas da memória relacionam-se com "as várias formas de as elites políticas, os grupos sociais e as instituições reinterpretarem o passado e a queda de civilidade, e propagarem novas narrativas interpretativas acerca de 'o que aconteceu', para legitimar uma nova administração política e desenvolver uma nova visão de futuro" (Brito, 2013, p. 43).

5 A expressão "um passado que não passa” deve-se a Conan e Rousso (1994), no âmbito do debate sobre a República de Vichy durante a II Guerra Mundial, cuja persistência na memória coletiva ainda assombra o presente da França.
} 
são contestados com êxito. Isto significa que a visibilidade e o reconhecimento de uma memória depende da força do grupo que a possui, como assinalou Enzo Traverso (2012, pp. 71-84) ao distinguir as "memórias fracas", subterradas e confiscadas, das "memórias fortes", oficiais e institucionalizadas e da relação privilegiada destas com a escrita da história. A memória do holocausto como "religião civil do mundo ocidental" (Traverso, 2012, p. 73) ilustra bem o processo de institucionalização de uma memória unificadora forte, representativa de todos os extermínios e atrocidades, que ofuscou tendencialmente as "memórias fracas" de genocídios políticos e étnicos em diferentes partes do mundo, os massacres coloniais em África e os desaparecidos das ditaduras latino-americanas e espanhola.

As dimensões problemáticas de passados que não passam e os seus usos políticos (Traverso, 2012, 2015) têm interessado cada vez mais a diferentes áreas do conhecimento, como a história, a ciência política, a antropologia e a sociologia. A produção de uma vasta literatura, reunindo diversas perspetivas de investigadores destas áreas, comprova a transversalidade teórica e analítica inerente à exploração do passado, com estudos sobre a memória, a justiça transicional ${ }^{6}$ e os processos de transição para a democracia a contribuírem, paralelamente, para a construção da memória pública das ditaduras ibéricas. ${ }^{7}$ Aos investigadores compete desenvolver o maior acervo de informações possíveis, que permitam refletir e estabelecer as diferenças entre as versões do passado que emanam de interesses políticos e rememorativos dos Estados e instituições, das versões subterradas que desvendam crimes contra a humanidade e vidas destruídas. O compromisso nasce da certeza de que o fundamento das sociedades democráticas, construídas após as ditaduras, radica no direito à verdade e à justiça, componentes decisivas para combater a desmemoria e novas formas de autoritarismo que ameaçam os valores da liberdade, igualdade e solidariedade, necessários ao futuro. A maior dificuldade reside no distanciamento dos investigadores face a objetos de estudo situados num passado

6 Os estudos da justiça transicional pertencem à política comparada e à ciência política. A justiça transicional inclui uma série de medidas [comissões da verdade, julgamentos, políticas de compensação, amnistias, saneamentos] adotadas no período de transição democrática para estabelecer uma rutura moral e política com o passado ditatorial (Brito, 2013, p. 42). Segundo António Costa Pinto "é uma componente de um processo de mudança de regime, cujas diferentes facetas são uma parte integrante deste processo incerto e excecional que tem lugar entre a dissolução do autoritarismo e a institucionalização da democracia” (Pinto, 2013, p. 13).

7 Entre outros, remeto para alguma da bibliografia utilizada neste trabalho: Casanova (2004); Brito et al. (2004); Espinosa Maestre (2006, 2015); Fuentes Aragonés (2008); Aguilar Fernández (2008); Vinyes (2011); Pinto et al. (2013); Manuel Loff et al. (2015); Pimentel (2017); Archilés e Sanz (2017). 
que viveram, ou do qual adquiriram uma "memória tomada de empréstimo" (Halbwachs, 2006, p. 72) por meio de publicações, filmes e testemunhos diretos que os inseriram num passado histórico comum.

Num artigo recente, Sherry Ortner (2019) analisou o compromisso dos antropólogos no desenvolvimento de trabalhos que procuram responder a questões do presente e atribuem visibilidade a problemas anteriormente ignorados pela antropologia. A autora, ao concluir a análise a partir da sua experiência e de outros autores, refutou a perspetiva de compromisso como "subjetiva”, "ideológica", "não científica” ou insuficientemente académica, por esta possuir uma adesão escrupulosa à análise das fontes e uma interpretação fundada em factos comprovados nos dados recolhidos. Isto significa que assumir uma posição de compromisso não impede a adesão aos princípios do rigor, factualidade e "verdade" inerentes a qualquer tipo de trabalho científico. E, "se existe uma verdade, a verdade é um campo de lutas" como observou Pierre Bourdieu (2001, p. 61), em que alguns académicos se enleiam em nome da objetividade, não deixando de expressar nos seus trabalhos preferências e tendências ideológicas.

O objetivo deste texto é questionar a construção das políticas da memória na primeira década da transição para a democracia, em Portugal e Espanha, a partir de dois casos que ressurgiram na pesquisa de um projeto anterior (Simões, 2013) sem encontrarem nele espaço de enunciação. O caso Os Anos do Século (1979), ${ }^{8}$ desencadeado pela exibição na televisão estatal portuguesa do primeiro documentário a questionar a guerra colonial e o apoio das hierarquias religiosa e militar ao regime fascista, numa conjuntura política de "desgonçalvização"9 dos meios de comunicação social. E o caso Rocío (1980), ${ }^{10}$ despertado pela receção do primeiro filme a recuperar as memórias da guerra civil e a ser sequestrado durante a transição espanhola, em defesa "del derecho al honor de personas afectadas por la libertad de información, sobre la represión franquista” (Espinosa, 2009, p. 41). Em ambos os casos, a verbalização e

8 Série sobre os principais acontecimentos do século xx com imagens de arquivo e testemunhos de diversas personalidades. Disponível em: https://arquivos.rtp.pt/programas/os-anos-doseculo/ [consultado em 12-12-2017].

9 O termo "desgonçalvização" foi utilizado pelas elites políticas de direita após o 25 de novembro de 1975, inclusive em debates parlamentares, para se referirem à necessidade de inverter as políticas implementadas pelo v Governo Provisório de Vasco Gonçalves (1975) na via para o socialismo, nomeadamente a "nacionalização e socialização dos meios de produção" consignadas no artigo 82..$^{\circ}$ da Constituição de 1976.

10 Versão do documental Rocío dirigido por Fernando Ruiz Vergara, estreado em 1980. Com partes censuradas aos 38'45", 40'45" e 43'30". Disponível em: https://www.youtube.com/watch?v $=$ vXJfp4iFAic [consultado em 12-12-2017]. 
publicitação de "memórias fracas", incómodas para uma parte da sociedade, interpelaram os poderes instituídos, mobilizaram os órgãos de comunicação social, desencadearam processos disciplinares e judiciais aos autores, e convocaram a opinião pública para um debate sobre o direito à memória e à liberdade de expressão. Os discursos produzidos à época por diversos atores sociais traziam à superfície da polémica o confronto entre grupos sociopolíticos com diferentes versões do passado. Por outro lado, as sanções aplicadas aos "prevaricadores" (realizadores, guionistas e intervenientes) colocaram a tónica na justiça transicional, como componente decisiva nos processos de transição para a democracia nas suas facetas de rutura revolucionária ou de "reconciliação" (Pinto, 2013).

A metodologia utilizada neste trabalho foi fundamentalmente bibliográfica e documental, complementada por conversas informais com os realizadores em tempos descontinuados, que ajudaram a iluminar as zonas sombrias das fontes escritas. Os casos entrelaçam experiências vividas, relações construídas e conhecimentos adquiridos pela autora em diferentes tempos e contextos, académicos e não académicos. A aproximação temporal e a relação empática estabelecida com os atores do passado podem sempre surgir à superfície do texto, e perturbar, por momentos inesperados de transferência, a desejada objetividade científica. O debate procura contribuir para o estudo dos processos de construção da memória pública das ditaduras como um "campo de poder" (Bourdieu, 2001) estruturado pelas relações de força entre as elites políticas e a sociedade civil, sempre que se encontram ameaçados os direitos democráticos alcançados e os equilíbrios políticos estabelecidos durante os processos de transição. Neste sentido, a análise dos casos enquadra-os em contextos histórico-sociais concretos, que os transformaram num campo de lutas, no interior do qual diferentes grupos e indivíduos se enfrentaram com meios e fins diversificados, contribuindo para preservar ou transformar as suas versões do passado e com elas as políticas da memória.

\section{OS PROCESSOS DE TRANSIÇÃO E AS POLÍTICAS DA MEMÓRIA}

Em Espanha, a memória da guerra civil foi confiscada e instrumentalizada pela propaganda do regime franquista (1939-1975) de forma a manter a sociedade dividida entre vencedores, detentores de todos os direitos e privilégios, e vencidos condenados à "muerte civil" (Casanova, 2004, p. 23). ${ }^{11}$

11 No quadro legislativo e judicial franquista destacam-se as leis de Responsabilidades Políticas de 9 de fevereiro de 1939 com efeitos retroativos a 1 de outubro de 1934, da Repressão da Maçonaria e do Comunismo de 1 de março de 1940, da Segurança do Estado de 29 de março $\rightarrow$ 
Em 1975 a morte do ditador não significou o fim do regime, mas a instauração da "Monarquia de 18 de Julho" de Juan Carlos de Bourbon, em conformidade com as denominadas "previsões sucessórias". No "Franquismo sem Franco" ${ }^{12}$ as instituições do Estado continuaram de pé, tudo ficou "atado e bem atado" e o ajuste de contas com o passado, levando os responsáveis do regime aos tribunais, "não fez parte da agenda política" (Ysás, 2015, p. 342). Numa sociedade de vencedores e vencidos os dirigentes políticos optaram por uma transição amnésica, por recearem outra guerra civil, "o que prova que a sua memória, ainda que subterraneamente, estava bem viva” (Traverso, 2012, p. 67). Na primeira etapa da transição (1976-1982), a decisão do governo da Unión de Centro Democrático (UCD) em destruir milhares de documentos dos arquivos da repressão (Falange, Guarda Civil e prisões provinciais) confirmava a "política del olvido" (Espinosa Maestre, 2006, p. 175). Com a aprovação da Lei da Amnistia de $1977^{13}$ o Estado renunciou a abrir no futuro qualquer investigação judicial sobre os "milhares de homicídios e violação dos direitos humanos praticadas por Franco e pelas suas forças armadas até ao final da ditadura” (Casanova, 2015, pp. 302-303). O "modelo español de impunidad"14 questionado por Equipo Nizkor, Amnistia Internacional e organismos de Direitos Humanos da onU, tem suscitado sucessivos pedidos de revogação da lei junto de diversos governos democráticos (Espinosa Maestre, 2015). Por esta constituir um poderoso obstáculo a processos por crimes contra a Humanidade, como no caso do primeiro

$\rightarrow$ de 1941 e da Ordem Pública de 30 de junho de 1952, concebidas para eliminar, castigar, torturar e humilhar os vencidos da guerra (Casanova, 2015, p. 301).

12 Expressão utilizada por José María de Areilza, alcalde de Bilbau (1937-1938), dirigente falangista, diretor-geral do Ministério de Indústria da Espanha (1940), embaixador na Argentina (1947-50) e Ministro de Assuntos Exteriores nomeado por Carlos Arias Navarro a 15 de dezembro de 1975 (Casanellas, 2017, p. 97).

13 A Lei aparentemente destinada a satisfazer os partidos de esquerda e os nacionalistas catalães e bascos represaliados conduziu a quatro diplomas legais que determinaram a reparação material destes grupos, atribuindo à justiça transicional a dimensão de "reparadora" (Pinto, 2013, pp. 33-34). No entanto, protegeu igualmente de ações judiciais "os perpetradores da ditadura" (Aguilar Fernández cit. em Humlebaek, 2013, p. 163). Ley 46/1977, de 15 de octubre, de Amnistía: "Artículo primero. I. Quedan amnistiados: a) Todos los actos de intencionalidad política, cualquiera que fuese su resultado, tipificados como delitos y faltas realizados con anterioridad al día quince de diciembre de mil novecientos setenta y seis. [...]”. Disponível em: https://www.boe.es/buscar/act.php?id=BOE-A-1977-24937 [consultado em 10-12-2018].

14 "La cuestión de la impunidad en España y los crímenes franquistas", Equipo Nizkor, relatório de 14-04-2004, Disponível em http://www.derechos.org/nizkor/espana/doc/impuesp.html [consultado em 10-12-2018]. 
documento judicial apresentado por 13 associações de memória histórica em 2006..$^{15}$

A justiça transicional e as políticas da memória não foram sinais de identidade da transição espanhola, apesar dos estudos pioneiros de historiadores que investigaram a repressão franquista (Gibson, 1971; Fraser, 1979; Moreno Gómez, 1982; Reig Tapia,1984; Solé i Sabaté y Villarroya, 1989 entre outros). A construção da memória pública do Franquismo forjou-se no mito da nação espanhola, na superação do passado bélico, na "reconciliação nacional" e na supremacia do Estado de Direito, claramente expressas no preâmbulo da Constituição de 1978:

La Nación española, deseando establecer la justicia, la libertad y la seguridad y promover el bien de cuantos la integran, en uso de su soberanía, proclama su voluntad de: Garantizar la convivencia democrática dentro de la Constitución y de las leyes Consolidar un Estado de Derecho que asegure el imperio de la ley como expresión de la voluntad popular. [...]. ${ }^{16}$

A partir da década de 80, o "mito da reconciliação" transformou-se numa ideologia de Estado (Vinyes, 2011), com a confiscação das memórias a ser seguida pelos governos maioritários do Partido Socialista Obrero Español (1982-1996).

A nível local, as políticas da memória preencheram os vazios éticos e emergiram no espaço público com homenagens a resistentes republicanos, que recordavam às comunidades a brutal ocupação das suas vilas e aldeias pelas forças sublevadas em $1936 .{ }^{17}$ As narrativas inicialmente produzidas sobre a repressão franquista surgiram como "memórias fracas", circunscritas às redes

15 "El derecho a la verdad y la obligación de investigar: el "caso Garzón” y las víctimas del franquismo en el Tribunal Supremo”. Disponível em: http://memoriahistorica.org.es/2-el-derech o-a-la-verdad-y-la-obligacion-de-investigar-el-caso-garzon-y-las-victimas-del-franquismo-en -el-tribunal-supremo/ [consultado em 10-12-2018].

16 Constitución Española aprobada por Las Cortes en sesiones plenarias del Congreso de los Diputados y del Senado celebradas el 31 de octubre de 1978, ratificada por el pueblo español en referéndum de 6 de diciembre de 1978 e sancionada por S. M. el Rey ante Las Cortes el 27 de diciembre de 1978, Disponível em: https://www.boe.es/legislacion/documentos/ConstitucionC ASTELLANO.pdf [consultado em 12-12-2018].

17 A 21 de setembro de 1980 o coletivo municipal de Oliva de la Frontera (Badajoz) transladou de uma fossa comum para um memorial no cemitério os seus fuzilados, inscrevendo na pedra: "Aquí reposan los restos de los oliveros que fueran muertos por sus ideales en la guerra civil española (1936-1939)". A 15 de agosto de 1988 um grupo de familiares e descendentes de represaliados republicanos reuniram fundos para a compra de uma placa que colocaram junto à fossa comum do cemitério de Rosal de la Frontera (Huelva) na qual podemos ler: "Homenaje a nuestros mártires por la democracia y la libertad 1936-1939". 
de sociabilidade afetiva e política dos grupos dos vencidos: republicanos, socialistas, anarquistas e comunistas. Nos finais da década de 90, o vazio ético que a transição amnésica instaurou na sociedade civil contribuiu decisivamente para a consolidação do movimento social pela recuperação da memória histórica (Acosta Abono et al., 2007; Aróstegui e Gálvez, 2010; Espinosa Maestre, 2015). $\mathrm{Na}$ linha das políticas de memória, verdade e justiça desenvolvidas pelos movimentos sociais da América Latina (Brito et al., 2004), o movimento espanhol alicerçou-se em associações regionais ${ }^{18}$ que inscreveram a memória antifranquista no espaço público, em memoriais, exposições, publicações, filmes, substituição da toponímia, mapeamento de fossas comuns e exumações dos restos mortais de milhares de republicanos fuzilados. ${ }^{19}$ Uma vasta produção historiográfica, antropológica e sociológica, realizada a partir de uma ampla e minuciosa pesquisa de arquivos e fontes orais a nível local e regional (Viñas e Blanco, 2017), acompanhou o movimento social e atribuiu visibilidade às memórias dos vencidos, aos presídios e campos de concentração franquistas, ao exílio republicano e aos desaparecidos do "holocausto espanhol" (Preston, 2011).

Em Portugal, o processo de democratização procedeu de uma revolução indissociável de uma cultura política progressista, antifascista e anticolonialista, cujo impacto na politização da sociedade justificou o preâmbulo da Constituição de 1976:

A 25 de Abril de 1974, o Movimento das Forças Armadas, coroando a longa resistência do povo português e interpretando os seus sentimentos profundos, derrubou o regime fascista. Libertar Portugal da ditadura, da opressão e do colonialismo representou uma

18 As associações de recuperação da memória histórica foram criadas a nível regional a partir do ano 2000, por familiares das vítimas da repressão franquista, advogados e investigadores de diversas áreas do conhecimento. Disponível em: https://memoriahistorica.org.es/que-es-la -asociacion-para-la-recuperacion-de-la-memoria-historica-armh-2000-2012/ [consultado em 12-12-2018]. Entre 2000 e 2018 procederam à abertura de 740 fossas comuns e exumaram os corpos de mais de 9000 pessoas fuziladas, a pedido dos familiares. Os dados de 2011, disponibilizados pelo Ministério da Justiça espanhol, apontam para a existência de 2591 fossas comuns e 120000 pessoas fuziladas. Disponível em: https://mapadefosas.mjusticia.es/exovi_externo/Carg arInformacion.htm [consultado em 12-12-2018].

19 Exumações realizadas ao abrigo da Ley de la Memória Histórica a partir de 2007. Ley $52 / 2007$, de 26 de diciembre, "por la que se reconocen y amplían derechos y se establecen medidas en favor de quienes padecieron persecución o violencia durante la guerra civil y la dictadura”. Esta Lei representou uma tentativa de reparação e dignificação das vítimas da repressão franquista como princípio democrático, mas primou pela ausência de processos judiciais aos responsáveis do regime franquista. Disponível em: https://www.boe.es/boe/dias/2007/12/27/ pdfs/A53410-53416.pdf [consultado em 12-12-2018]. 
transformação revolucionária e o início de uma viragem histórica da sociedade portuguesa. A Revolução restituiu aos Portugueses os direitos e liberdades fundamentais [...]. ${ }^{20}$

A identidade revolucionária da democracia portuguesa foi forjada na continuidade da resistência antifascista e no Movimento das Forças Armadas (MFA), "autoconstituído como uma espécie de braço armado do Povo (Loff, 2015, p. 26). Entre 1974 e 1976 foi colocada a tónica numa justiça transicional que conduziu ao desmantelamento da polícia política e organizações repressivas, a saneamentos e reformas compulsivas de colaboradores do regime, levou a tribunal alguns agentes da polícia política e deixou ilesos os principais responsáveis (Raimundo, 2013 e Pimentel, 2017). No âmbito das políticas da memória assistiu-se à hegemonia das memórias da resistência antifascista, através de biografias de militantes socialistas, comunistas e anarco-sindicalistas, com alguns a destacarem a participação portuguesa na guerra civil espanhola (Miguel, 1977; Firmo, 1978). Relativamente às memórias da Guerra Colonial surgiram publicações produzidas clandestinamente nos últimos anos da ditadura, por associações de católicos progressistas, que atribuíram visibilidade aos massacres perpetrados em Angola, Moçambique e São Tomé e fundiram a memória antifascista portuguesa com a memória da resistência anticolonial africana (Loff, 2015, p. 31).

O golpe militar "contrarrevolucionário" de 25 de Novembro de 1975 alterou a correlação de forças políticas na sociedade portuguesa, com os vencedores a imporem "a consagração da legitimidade eleitoral sobre a legitimidade revolucionária" e a reposição da hierarquia tradicional das Forças Armadas sobre o MFA (Rosas, 2015, p. 203). As clivagens políticas então verificadas fixaram um novo padrão na abordagem das várias forças sociopolíticas às políticas da memória da ditadura, da Revolução e da Guerra Colonial. Em 1977 a direita portuguesa quebrou o consenso semântico ao recuperar a nomenclatura salazarista de ultramar versus colonialismo, terrorismos (campanhas em África) versus guerra colonial. E generais fiéis à ditadura publicaram a obra África. A Vitória Traída (1977), que serviu de fonte a um discurso memorialista que silenciava a dominação portuguesa em África, o direito à autodeterminação das populações subjugadas e as injustiças da guerra (Loff, 2015, pp. 51-53).

A atitude do Estado português modificou-se ao longo dos anos, entre o silenciamento e a legitimidade da guerra, em função dos ciclos políticos. $\mathrm{Na}$ década de 80, a Comissão de Estudo das Campanhas de África (1961-1974), 
nomeada pelo governo da Aliança Democrática (AD) ${ }^{21}$ institucionalizou uma "memória forte" que esmagou as "memórias fracas" do colonialismo português e da violação dos direitos humanos em África. Por outro lado, a generalidade dos estudos de opinião mostraram sempre que maioria da população nunca aceitou a descolonização, que "foi a condição essencial para a democratização da sociedade portuguesa” (Loff, 2015, p. 53). A memória valorizadora da "África perdida", articulada com a ideia "de uma descolonização atabalhoada e profundamente lesiva, criou o pano de fundo para a proliferação de imagens nostálgicas de timbre lusotropicalizante, que tendem a omitir o papel da violência colonial", como salientou Miguel Cardina (2017, p. 86). A herança traumática de um passado por exorcizar produziu e continua a produzir múltiplas narrativas e com elas políticas da memória "que silenciam o objeto histórico" (Cardina e Sena Martins, 2018). Este processo confunde-se com a história dos portugueses nas últimas quatro décadas, "com as suas esperanças e as suas desilusões, com a conquista e a perda de direitos, com a adesão e rejeição do sistema político criado entre 1974 e 1976" (Loff, 2015, p. 29).

\section{O CASO OS ANOS DO SÉCULO E A “DESGONÇALVIZAÇÃO” DA COMUNICAÇÃO SOCIAL}

[...] O povo português, com o 25 de Abril, conquistou o direito de discutir a sua história, a passada e a presente, sobretudo o passado recente de que foi mais objecto e instrumento do que motor, e aí cabe lugar especial à guerra colonial. [...] Esconder às gerações actuais e vindouras as consequências desastrosas da guerra colonial [...] seria claramente tentar manobrar a história $\left[\ldots . .{ }^{22}\right.$

O Ministério da Comunicação Social foi criado em maio de $1974^{23}$ e o cargo ministerial desempenhado por diversas personalidades civis e militares. ${ }^{24}$ Em março de 1975 decretou-se que a Rádio Televisão Portuguesa (RTP) deveria refletir e respeitar nos seus programas "o pluralismo político cultural da sociedade portuguesa, daí cometer-se aos partidos políticos a sua fiscalização, com a possibilidade do envio de reclamações escritas". ${ }^{25}$ A Lei de

21 Coligação de centro-direita formada em 1979 pelo Partido Social Democrata (PSD), Centro Democrático Social (CDS) e Partido Popular Monárquico (PPM).

22 Declaração de José Matias de Vasconcelos, porta-voz da Associação dos Deficientes das Forças Armadas prestada a O Jornal, de 30 de março (Gago, 1979, p. 172).

23 Diário do Governo, I Série, n. ${ }^{\circ}$ 113, de 15-05-1974.

24 Legislação histórica sobre comunicação social, disponível em http://www.gmcs.pt/ficheiro s/pt/legislacao-historica-sobre-comunicacao-social-1974-1990.pdf [consultado em 12-12-2017).

25 Diário do Governo, II Série, n. ${ }^{\circ}$ 67, de 20-03-1975. 
Imprensa de 1975, primeiro diploma regulador do sector da informação, "funcionou como legislação subsidiária para a televisão e a rádio" (Mesquita, 1994, p. 367). Em dezembro do mesmo ano, o Estado nacionalizou a RTP no âmbito das nacionalizações de posições sociais que detinha no capital de várias sociedades que exerciam a atividade de radiodifusão em território continental. ${ }^{26}$ Com a aprovação da Constituição de 1976, a liberdade de expressão e informação, a liberdade de imprensa, os meios de comunicação social do Estado e o direito de antena deram corpo a quatro artigos da Lei Fundamental. ${ }^{27} \mathrm{O}$ artigo $37 .^{\circ}$ determina que "todos têm o direito de exprimir e divulgar livremente o seu pensamento pela palavra, pela imagem ou por qualquer outro meio, bem como o direito de se informar, sem impedimentos nem discriminações" e que o "exercício destes direitos não pode ser impedido ou limitado por qualquer tipo ou forma de censura”. Segundo Mário Mesquita (1994), o articulado denotava "o esforço quase obsessivo para conjugar os fantasmas censórios do antigo regime e as novas censuras que os desvios da Revolução, interpretada pelas Forças Armadas, traziam no bojo", considerando que a proibição de todas as formas e tipos de censura "aludia indiretamente a formas de censura operatórias" (1994, p. 383).

Em 1979, superados "os desvios da Revolução", as "formas de censura operatórias" eram enunciadas num artigo de Augusto de Carvalho:

O caso, "Anos do Século", veio provar à saciedade que continua a grassar em Portugal nos sectores da Comunicação Social, uma metodologia característica dos tempos do fascismo. [...] Todos nós sabemos que o fascismo agia nos meios da Comunicação Social, de várias maneiras, sendo duas as principais: a censura e o afastamento das pessoas que não estavam dispostas a dizer o que ia convindo ao pensamento oficial. [...] E o fascismo justificava-se sempre em nome dos supremos interesses nacionais [...] [Gago, 1979, p. 279].

Os Anos do Século foi a primeira série documental da RTP sobre o século xx português a contribuir para a construção da memória pública da ditadura, através do questionamento da repressão da polícia política (PIDE/DGS), da guerra colonial e do apoio da hierarquia da igreja ao regime. ${ }^{28} \mathrm{~A}$ série foi

26 Diário do Governo, $2 .^{\circ}$ Suplemento, I Série, n. ${ }^{\circ} 278$, de 2-12-1975.

27 Artigos $37 .^{\circ}, 38 .^{\circ}, 39 .^{\circ}$ e $40 .^{\circ}$ da Constituição Portuguesa, aprovada em 02-04-1976, p. 9, Disponível em https://www.parlamento.pt/parlamento/documents/crp1976.pdf [consultado em 12-12-2017].

28 Na série Os Anos do Século fundiram-se duas propostas de programas: "Ascensão, agonia e morte do Estado Novo" (1976) de José António Saraiva e "O país e o Palácio de Belém” (1977) de José Elyseu, que refletiam a preocupação dos autores e da televisão estatal pelo passado $\rightarrow$ 
aprovada durante o I Governo Constitucional (1976-1978) do Partido Socialista $^{29}$ e respondia às preocupações do executivo de Mário Soares, que identificava "a expansão de ideologias neofascistas na sociedade portuguesa" e a urgência no "esclarecimento da opinião pública acerca dos crimes, violências e abusos praticados durante quase meio século em Portugal pelo regime derrubado em 25 de Abril de 1974" ${ }^{30}$ A exibição da série iniciou-se no IV Governo Constitucional (1978-1979) do Partido Social-Democrata, ${ }^{31}$ num contexto político que Eduardo Lourenço classificou "de nacional saudosismo", em que tudo "o que contrariar a mitologia cultural e ideológica do antigo regime não tem direito de cidade na televisão liberta pelo 25 de Abril" (Gago, 1979, pp. 138-139). Em 2011, o ex-ministro da Comunicação Social recordava o convite para o cargo em 1979 nos seguintes termos: "a comunicação social estava ainda dominada pelas forças revolucionárias. A televisão era do Estado, a rádio, idem aspas. Havia ali um grande desafio; "desgonçalvizar" a tomada dos meios de comunicação social". ${ }^{32}$ A confiscação absoluta desses meios, que foram a essência do regime deposto a 25 de Abril, era instrumentalizada

$\rightarrow$ ditatorial. Algumas incompatibilidades formais e ideológicas conduziram à rutura entre os dois proponentes, ficando os 12 episódios da série programados pela seguinte ordem: $1 .{ }^{\circ}$ - "O 5 de Outubro"; $2 .^{\circ}$ - "A I República Portuguesa"; $3 .^{\circ}$ - "O 28 de Maio de 1928”; $4 .^{\circ}$ - "A construção do Estado corporativo; $50^{\circ}$ - "Portugal e o fascismo na Europa"; $6 .^{\circ}$ - "O benefício da Guerra Fria"; 7. - "O isolamento de uma nação"; $8 .^{\circ}$ - "Do regime à oposição - Humberto Delgado"; $9 .^{\circ}$ - "O exílio - Humberto Delgado"; 10. - "A Operação Outono - Humberto Delgado; 11. - "A guerra inútil" e 12. - "A evolução na continuidade". Os primeiros três episódios tiveram argumento e textos do Arq. José António Saraiva. Os episódios sobre Humberto Delgado tiveram argumento de José Elyseu e textos do Eng. ${ }^{\circ}$ Mauricio Garcia e do jornalista Augusto de Carvalho. Os restantes episódios, entre os quais o $11^{\circ}$, tiveram argumento de José Elyseu e textos do historiador César Oliveira. Arquivo particular gentilmente cedido por José Elyseu.

29 Manuel Alegre desempenhou as funções de Secretário de Estado da Comunicação Social e João Soares Louro de subsecretário. Diário da República, Suplemento, I Série, n. ${ }^{\circ} 175$, de 28 de Julho de 1976.

30 Ata da reunião do Conselho de Ministros, de 6 de janeiro de 1977. Proposta para a formação da Comissão do Livro Negro do Fascismo. Pontos prévios: 4, página 6, Disponível em: http://casacomum.org/cc/visualizador?pasta=00791.001\#!1 [consultado em 10-12-2018].

31 Daniel Proença de Carvalho desempenhou as funções de ministro da Comunicação Social. Diário da República, 2. ${ }^{\circ}$ Suplemento, I Série, n. ${ }^{\circ}$ 269, de 22 de novembro de 1978. João Soares Louro era presidente da Comissão Administrativa da RTP. Diário da República, II Série, n. ${ }^{\circ} 72$, de 28 de março de 1978. Em 1980, durante o vi Governo Constitucional (AD) João Soares Louro foi substituído por Daniel Proença de Carvalho, que desempenhou o cargo de presidente de Administração da RTP entre 1980-1983. Diário da República, Suplemento, II Série, n. ${ }^{\circ} 41$, de 18 de fevereiro de 1980 .

32 Entrevista a Anabela Mota Ribeiro, Disponível em http://anabelamotaribeiro.pt/76253. html [consultado em 12-12-2017]. 
com novos propósitos: antidemocráticos para as forças de esquerda e de normalização democrática para as de direita. ${ }^{33}$ Neste contexto tornava-se "evidente que a série agora programada não podia ser vista, nem recebida com os mesmos olhos do tempo em que foi concebida", como assinalou Eduardo Lourenço à época (1979, p. 137).

A 5 de março de 1979, após a exibição do $11 .^{\circ}$ episódio "A guerra inútil",34 o locutor de continuidade leu um comunicado da Comissão Administrativa da RTP, que anunciava o posicionamento político da estação pública: "O programa que acabámos de transmitir (...) representando quanto ele encerra o ponto de vista dos seus autores e realizador sobre os acontecimentos do período de tempo a que respeitam" (1979, p. 30). As imagens da guerra colonial ressurgiram aos olhos dos portugueses com uma nova narrativa, de rutura com o passado e questionamento do colonialismo português, estabelecendo conexões entre o regime fascista e as hierarquias religiosa e militar na manutenção da guerra, discurso que indignou os sectores mais conservadores da sociedade portuguesa. A 6 de março, um novo comunicado informava os telespetadores que "o programa provocara a viva repulsa em largas camadas da população, apresentando passagens extremamente ofensivas dos sentimentos do povo português", justificando-se as seguintes deliberações:

a) retirar definitivamente das listas de colaboradores da RTP os principais responsáveis pela autoria do programa em causa e submeter o mesmo a parecer do Conselho de Programas;

b) suspender de todas as funções o realizador Sr. José Elyseu, ${ }^{35}$ para apuramento total das suas responsabilidades;

c) suspender a transmissão da série Os Anos do Século até que o Conselho de Programas se prenunciasse sobre o episódio que faltava exibir;

33 Na sequência do golpe militar de 25 novembro de 1975, 152 trabalhadores da comunicação social estatizada (RTp, Emissora Nacional, Rádio Clube Português, Diário de Notícias, Século, Jornal do Comércio e ANOP) foram suspensos sem culpa formada, através de "um processo exclusivamente político-partidário". Impedidos de entrarem nos locais de trabalho e sem salário, homens e mulheres recorreram aos Tribunais do Trabalho, da Relação e do Supremo. Anos mais tarde venceram os processos e foram indemnizados, mas "muitas carreiras profissionais foram arruinadas e dezenas de vidas pessoais e familiares destruídas” (Cardoso, 2017).

34 “A Guerra Inútil”. Disponível em https://arquivos.rtp.pt/conteudos/a-guerra-inutil-parte-i/ e em https://arquivos.rtp.pt/conteudos/a-guerra-inutil-parte-ii/ [consultado em 12-12-2017].

35 José Elyseu (Lisboa, 1936) funcionário da RTP desde 1961 e militante do Partido Socialista desde 1974, fez a sua formação como realizador na ввC e foi autor de centenas de documentários históricos, culturais e de artes plásticas, Disponível em: https://arquivos.rtp.pt/page/1/?advanced $=1 \& \mathrm{~s}=\mathrm{Jos} \% \mathrm{C}_{3} \% \mathrm{~A} 9+$ Elyseu [consultado em 12-12-2017]. 
d) finalmente: lamentar esta ocorrência e assegurar ao público que, de futuro, tudo será feito para obviar situação análogas (Gago, 1979, p. 50).

A 7 de março, o comunicado dividiu o Conselho de Informação para a RTP reunido em São Bento, com os deputados do CDS a abandonarem a reunião por "não pretenderem legitimar perante os portugueses as deliberações que são contrárias aos seus interesses e apenas servem os saudosos do gonçalvismo" (Gago, 1979, p. 50). O discurso encontrava expressão no artigo "A televisão do Estado contra Portugal" de Adelino Alves, publicado no jornal O Dia (1975-1988):

[...] Não restam dúvidas de que os autores do vil programa, apadrinhados - digam o que disserem pelos responsáveis da RTP, estão tentados a intoxicar a opinião pública, segundo os melhores métodos marxistas-leninistas. [...] Mentir, insinuar, atraiçoar, tudo é permitido, conquanto consigam alcançar os seus asquerosos fins! [...] É sabido que a grande maioria dos portugueses respeita os valores que a RTP decidiu conspurcar, vomitando ódio sobre a nossa História [...] Caso é de se perguntar se haverá depois deste vómito, razão moral para que continuem nesse propósito [...] [Gago, 1979, p. 48].

A 8 de março, no jornal A Capital (1968-2005), o historiador César Oliveira respondeu ao comunicado na qualidade de autor, lamentando o pedido de desculpas da estação estatal por "ter denunciado o colonialismo e os apoios que o regime fascista teve, entre eles o da alta hierarquia da Igreja Católica". Em relação às penalizações, salientou que a RTP "absolveu assim o fascismo, o colonialismo e a repressão, e pelos inquéritos instaurados institucionaliza a autocensura e espalhava o medo entre os trabalhadores da televisão" (Gago, 1979, p. 52-53). Na primeira página d'O Diário (1976-1990) denunciava-se a violação do direito à informação e liberdade de expressão na televisão estatal, num artigo intitulado "Repressão e censura oficializadas. Minoria fascista impõe-se à RTP. Forças democráticas exprimem repúdio popular" (1979, p. 51).

$\mathrm{Na}$ Assembleia da República, os partidos com representação parlamentar consagraram a reunião plenária de 8 de março à discussão do caso (Gago, 1979, pp. 189-250), debatendo a moção de repúdio apresentada pela Comissão Parlamentar de Direitos, Liberdades e Garantias, aprovada com 14 votos a favor (PS e PCP) e nove contra (PSD e CDS). ${ }^{36}$ A moção manifestava a profunda

36 Diário da Assembleia da República, 1. ${ }^{\text {a }}$ série, n. ${ }^{\circ}$ 36, de 9 de março de 1979, citado pelo deputado independente social democrata Magalhães Mota, aquando do requerimento apresentado ao presidente da Assembleia da República a 18 de maio de 1979, de um pedido $\rightarrow$ 
preocupação e reprovação pela política repressiva exercida nos órgãos de comunicação social, por meio de processos censórios que punham em causa "as liberdades consagradas constitucionalmente, nomeadamente a liberdade de expressão e a liberdade de informação" (1979, p. 189). Na noite do mesmo dia, em entrevista ao programa "Diretíssimo", o presidente da Comissão Administrativa da RTP afirmava ter considerado "o programa cruel e manipulador", justificando o processo disciplinar ao realizador e a suspensão da série nas pressões recebidas "de todas as forças políticas e de todas as forças sociais". ${ }^{37}$

A 13 de março, o cardeal patriarca, após reunião com os bispos auxiliares, emitiu uma nota divulgada nos jornais de direita O Dia (1975-1988), O Tempo (1975-1990) e O Diabo (1976-1983):

[...] Logo vivamente denunciado pela opinião pública, este programa foi, na verdade, a vários títulos, indigno e chocante: revelou-se manipulador e desonesto de documentos e factos, careceu de objectividade histórica; ofendeu gravemente a memória do Papa João Paulo II e do Cardeal Cerejeira. Tudo isto redundou, de modo claro, num insidioso ataque à Igreja Católica. [...] [Gago, 1979, p. 80].

O Dia destacou as palavras do arcebispo-primaz de Braga, classificando o documentário de "guerrilha de esquerda" e "a ausência de escrúpulos de historiadores e realizadores que agridem e destoem os sentimentos religiosos de um povo milenar, que já era católico, antes de ser português”. A responsabilização pela "ignóbil afronta" recaía na "maioria de esquerda que tudo tem obstruído, evitando a instauração da normalidade democrática”, bem como nos órgãos da comunicação social que perpetuavam, em seu entender, "uma contínua intoxicação do País, desde que uma ditadura de cariz marxista, apoiada militarmente, se apoderou do aparelho do Estado pouco após a Revolução de Abril” (Gago, 1979, pp. 118-120). Os discursos proferidos por representantes da hierarquia

de esclarecimentos à RTP sobre o processo instaurado ao realizador José Elyseu, Disponível em http://debates.parlamento.pt/catalogo/r3/dar/s2/o1/03/063/1979-05-19/1534?q=Elyseu [consultado em 12-12-2017].

37 Segundo o Despacho n. ${ }^{\circ}$ 35/79 da Comissão Administrativa da RTP: atenta a gravidade objetiva de passagens do filme Os Anos do Século, transmitido no 1. ${ }^{\circ}$ Programa da RTP, na emissão de 5 de Março de 1979 (...) Atendendo a que a conduta indiciada, imputável ao realizador José Elyseu, integra as normativos da alínea g) cláusula 93. ${ }^{\mathrm{a}}$ do Acordo Colectivo de Trabalho em vigor, e do artigo $10 .^{\circ}$ do Decreto-lei n. ${ }^{\circ}$ 91-A/77 de 11 de março também em vigor: a Comissão Administrativa da RTP-EP, determina: 1. Instaurar procedimento disciplinar ao realizador José Elyseu; 2. Suspendê-lo do exercício das suas funções atento que a sua presença se mostra inconveniente face à gravidade da conduta indiciada. Lisboa, 9 de março de 1979, A Comissão Administrativa, João Soares Louro e duas assinaturas ilegíveis (Gago, 1979, p. 37). 
da igreja foram amplamente contestados por sectores católicos progressistas. Helena Cidade Lisboa defendeu "ser possível ser católico e considerar que o filme tem aspetos largamente positivos” (1979, p. 86). Luísa Sarsfield Cabral, no jornal Jovem Socialista, recordava a participação dos católicos progressistas na luta contra a ditadura, referindo os exílios, as prisões e a repressão da PIDE/ /DGs sobre sacerdotes e coletivos que se manifestaram em defesa da Paz, contra a Guerra Colonial (1979, pp. 178-179).

A 14 de março, o vice-chefe do Estado Maior General das Forças Armadas expressava o posicionamento político da instituição militar relativamente ao programa, como um "insulto generalizadamente dirigido aos portugueses que estiveram nas Forças Armadas". Mas recusou o convite da RTP para que um representante das FA participasse num debate a realizar após a exibição do $12 .^{\circ}$ episódio, último da série, que à época nunca foi emitido. A hierarquia militar que controlou as Forças Armadas após a vitória eleitoral do general Ramalho Eanes (1976) adotara um discurso revisionista sobre o colonialismo e a guerra colonial (Loff, 2015; Soutelo, 2015). Neste contexto, a participação do capitão António Calvinho ${ }^{38}$ no programa denunciando a crueldade da guerra, os mortos e estropiados e o apoio das hierarquias religiosas e militares à política colonial do regime fascista representou uma traição à instituição militar, punida com cinco dias de prisão. ${ }^{39}$

Ao longo de quatro meses, o caso Os Anos do Século transformou-se num intenso campo de lutas, no interior do qual se enfrentaram diferentes forças sociais e políticas, com meios e fins diversificados, em defesa dos direitos conquistados com a Revolução e dos acordos estabelecidos pelas elites políticas após a contrarrevolução. ${ }^{40} \mathrm{Na}$ sequência da suspensão de funções e da receção de ameaças anónimas o realizador José Elyseu instaurou um processo judicial à RTP, ${ }^{41}$ fundamentado nas perseguições políticas e nas ofensas e calúnias de que fora alvo. A 27 de junho de 1979, a RTP arquivou a ordem de suspensão do realizador e reintegrou-o nas suas funções. O processo judicial arrastou-se nos tribunais até maio de 1981 e encerrou com a indemnização do lesado. Mas o

38 Fundador e ex-presidente da Associação dos Deficientes das Forças Armadas, fundada a 14 de maio de 1974, e autor dos livros Trinta Facadas de Raiva (1976) e O Deus que a Igreja nos Vende (1977), editados por esta associação.

39 "Capitão Calvinho saiu da prisão mas espera-o novo processo", Diário de Lisboa, 22-03-1979, p. 24.

40 Vasco Lourenço, Raul Rego, Eduardo Lourenço, José Gomes Ferreira, Maria Velho da Costa, Mário Dionísio, Augusto Abelaira, José Niza, Jorge Listopad, João Bénard da Costa, entre outros, escreveram artigos de opinião, que juntamente com comunicados e atas foram reunidos no livro Os Anos do Século. Poder Político e Comunicação Social (1979).

41 Defendido pelo jurista e dirigente do Partido Socialista Victor Ramalho. 
caso marcou indelével a vida pessoal e profissional de José Elyseu, impedindo-o de realizar projetos de cariz político. "A direita nunca perdoa..." foi a expressão utilizada ao recordar o sistemático adiamento da série Portugal e a Guerra Civil de Espanha em 1986, que apesar de aprovada pela Direção de Programas nunca se realizou. ${ }^{42}$ Em causa estava o questionamento das ditaduras ibéricas, o apoio incondicional de Salazar ao golpe militar e à repressão franquista, e a dignificação dos antifascistas portugueses no apoio à II República espanhola. ${ }^{43}$ Os passados silenciados ressurgiram emaranhados a inquietar o presente, num contexto político dominado pelo x Governo Constitucional (1985-1987) do PSD. A hegemonia política que se seguiu, com as maiorias absolutas dos governos de Aníbal Cavaco Silva (1987-1995), iniciou um novo ciclo na sociedade portuguesa em que não interessava à direita discutir o passado, por este suscitar "afinidade com certos princípios ético-políticos e a herança política da ditadura" como salientou Luciana Soutelo (2015, p. 575).

\section{ROCÍO: O FILME SEQUESTRADO PELA TRANSIÇÃO}

[...] La diferencia entre la censura de las dictaduras y la de las democracias es más de contenido ideológico (de lo que son los valores protegibles en cada momento) que de existencia o inexistencia de la misma [...] [Álvarez González, 2007, p. 8].

O cinema documental em Espanha viveu momentos frutíferos durante o primeiro período da transição (1976-1981), com obras que preencheram o vazio proibitivo do regime franquista. Destacam-se os documentários: El Desencanto (1976) dirigido por Jaime Chávarri; Canciones para después de una guerra (1971) realizado na clandestinidade por Basilio Martín Patino e estreado em Barcelona em 1976; El Crimen de Cuenca (1979) dirigido por

42 Série documental de oito episódios de 50', aprovada em Maio de 1986, com emissão prevista para Março de 1987, com textos do historiador César Oliveira. realizada a partir de imagens de arquivo (RTP, TVE, BBC, ORTF, Cinemateca Nacional e Cinemateca Francesa), entrevistas e imagens filmadas em Portugal e Espanha. Sinopse: "uma contribuição importante, não apenas para preencher lacunas significativas na historiografia portuguesa contemporânea, mas como uma homenagem aos que, num ou noutro campo, tombaram em Espanha na defesa dos seus ideais". Ficha de Programas n. ${ }^{\circ}$ 86114104074/081. "Dossier Portugal e a Guerra Civil de Espanha, arquivo particular.

43 Textos construídos a partir da tese de doutoramento de César Oliveira, publicada em 1986 sob o titulo: Salazar e a Guerra Civil de Espanha, Lisboa, O Jornal. A 3 de outubro de 1986 César Oliveira contactou telefonicamente o realizador José Elyseu afirmando "não compreender a atitude da RTP", disposto a expor o assunto ao Conselho de Gerência. Dossier Portugal e a Guerra de Espanha. Arquivo particular. 
Pilar Miró, proibido pelo ministro da Cultura Ricardo de la Cierva por ofender a Guarda Civil (Alvarado, 2013, p. 67) e Rocío (1980) de Fernando Ruiz Vergara ${ }^{44}$ o primeiro filme a ser sequestrado judicialmente durante a transição.

A revogação da Censura em novembro de 1977 e a Constituição de 1978 criaram expectativas de liberdade de expressão. O artigo 20. ${ }^{\circ}$ da Constituição estabelecia o direito de "expresar y difundir libremente los pensamientos, ideas y opiniones mediante la palabra, el escrito o cualquier otro medio de reproducción". Direito este restringido "en los preceptos de las leyes que lo desarrollen y, especialmente, en el derecho al honor". A salvaguarda do direito à honra prevalecia sobre o direito ao conhecimento, submetida ao poder judicial, prevendo "acordarse el secuestro de publicaciones, grabaciones y otros medios de información en virtud de resolución judicial". ${ }^{45}$ Neste sentido, a censura democrática "se desarrolla por parte de las élites dominantes, que pretenden evitar desviaciones sociales inconvenientes para el status quo", como observou Norberto Álvarez (2007, p. 7).

Rocío partiu de uma visão histórica e antropológica da famosa romaria andaluza de Huelva, legitimada por historiadores e antropólogos, e estabeleceu relações entre um fundador da Hermandad da Virgen de Rocío de Jerez de la Frontera e a repressão franquista de 1936 em Almonte (Huelva). A violência que se abateu sobre os republicanos de Almonte em agosto de 1936 provocou o assassinato de 100 pessoas, 99 homens e uma mulher. O crime ignóbil permaneceu indelével na memória coletiva de familiares e vizinhos e emergiu de forma pungente nos écrans dos cinemas, por meio da sucessão de imagens e narrativas que identificavam as vítimas e o principal perpetrador, José María Reales Carrasco. As "memórias fracas" da repressão franquista quebravam o "pacto de olvido" e avassalavam o público com o testemunho de Pedro Gómez Clavijo:

44 Fernando Ruiz Vergara (Sevilha, 1942 - Escalos de Baixo (Castelo Branco - Portugal), 2011) viveu a infância e juventude em Huelva, frequentou a Escola Ferroviaria, a San Casiano e a Academia San Carlos. Em Portugal fundou a Iberlivro e o Centro de Intervenção Cultural (CIC) em 1975, organizou a I Mostra Internacional de Cinema de Intervenção em 1976. Em Espanha fundou a Tangana Films - Producciones Cinematográficas Andaluzas em 1977. Venceu o $1^{\circ}$ prémio de I Festival Internacional de Cine de Sevilha em 1980. Deixou por concretizar diversos projectos audiovisuais e expositivos, como a exposição "Huelva y... Huelva", encomenda da Diputación de Huelva.

45 Constitución Española, aprobada por Las Cortes en sesiones plenarias del Congreso de los Diputados y del Senado celebradas el 31 de octubre de 1978, ratificada por el pueblo español en referéndum de 6 de diciembre de 1978 e sancionada por S. M. el Rey ante Las Cortes el 27 de diciembre de 1978. Disponível em: https://www.boe.es/legislacion/documentos/ConstitucionCASTELLANO.pdf [consultado em 12-12-2018]. 
[...] pues ese señor cuando había una saca de hombres, obreros, luchadores por la libertad, el pan y el trabajo les decía a los de la banda criminal: "! - No empezad todavía, dejarme los míos a mí!”, y montando en un caballo, con un porro los mata a palos. ${ }^{46}$

Rocío denunciava a violência que alguns historiadores confirmaram anos mais tarde, quando investigaram exaustivamente os arquivos da repressão para concluírem que na Andaluzia e Extremadura não houve guerra, apenas violência e terror (Moreno Gómez, 1982; Espinosa Maestre, 1996, 2003; Cobo Romero, 2004 entre outros). Desde a fase conspirativa do golpe militar de 18 de julho de 1936 que a destruição do sistema democrático obedeceu a um "plano de extermínio" dos seus representantes e das ideias que iluminaram a II Republica, "para el presente y para el futuro" (Espinosa Maestre, 1996, p. 397). Em 2007, a Asociación Andaluza Memoria Histórica y Justicia de Andalucía (Aмнyja) veio corroborar a teoria do "plano de extermínio" que Paul Preston (2011) designou de "holocausto espanhol", com o mapeamento de 708 fossas

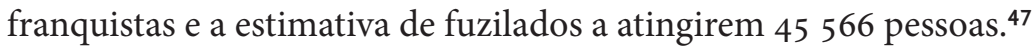

A 18 de julho de 1980 Rocío foi estreado em Alicante, coincidindo com a inesquecível data que implementara o "plano de extermínio" revelado no filme por Fernando Vergara. Em outubro de 1980 venceu o $10^{\circ}$ prémio do I Festival Internacional de Cine de Sevilha e foi selecionado pelo Ministério da Cultura para o Festival de Cinema de Veneza, juntamente com Opera Prima de Fernando Trueba. A estreia em diferentes cidades espanholas foi amplamente divulgada na imprensa, em críticas cinematográficas e colunas de opinião. $\mathrm{Na}$ imprensa andaluza o filme gerou controvérsia e mobilizou as forças políticas e sociais mais conservadoras. No jornal Movimiento Sur/Oeste, de 23 de outubro de 1980, o artigo de opinião "A Rocío le sobraron palmas" destacava:

[...] Junto a partes de inestimable valor, por su fisicidad, inmediatez y ágil visión del problema en su conjunto, tenemos otras enormemente perjudicadas por un innecesario énfasis en el ataque, a veces infantil y decididamente panfletario, a instituciones y poderes como la Iglesia, los terratenientes en general, los falangistas, las derechas y, en una palabra, el franquismo, al que se le acusa de manipular el tema del Rocío para su provecho [Del Río Sánchez e Espinosa Maestre, 2013, p. 80].

46 Depoimento de Pedro Gómez Clavijo em Rocío, dos 43’40" aos 44’30", Disponível em: https://www.youtube.com/watch?v=_esOhwj6eEQ [consultado em 12-12-2017].

47 Projeto "Todas las fosas" financiado pela Consejeria de Justicia e Administración Pública da Junta de Andalucía, realizado ao abrigo da Ley de la Memoria Histórica, para exumação e dignificação das vitimas da repressão franquista, Disponível em: https://www.juntadeandalucia. es/organismos/culturaypatrimoniohistorico/areas/memoria-democratica/fosas/mapas-fosas. html, [consultado em 12-12-2018]. 
A 4 de fevereiro de 1981, numa sessão em Madrid, no Cine Bellas Artes, foi aplaudido por dirigentes socialistas, escritores e poetas andaluzes como Alfonso Guerra, Antonio Gala, Fernando Quiñones e José Caballero Bonald. O jornal madrileno Diári 16 e o valenciano La Calle publicaram críticas favoráveis, e a 3 de fevereiro de 1981 o reconhecido crítico cinematográfico Fernando Lara aconselhava: "verla, para que se sepa un poco mejor en qué país vivimos" (Espinosa Maestre, 2009, p. 45). A 15 de fevereiro no artigo "La mala sombra del Rocío", publicado em El Correo de Andalucía, o padre jesuíta José María de Sobrino, crítico de cinema, afirmava:

[...] resulta que íbamos a ver una película del Rocío y nos han largado un mitin político y anticlerical, que termina con un canto a las manos de los trabajadores que tienen que conseguir la libertad” (...) “¿A qué vienen esos recuerdos de de las crueldades de la guerra civil en un bando? ¿Es que no los hubo en los dos? ¿No sería más español y más democrático, no revivir escenas lamentables del pasado? [...] [Del Río Sánchez e Espinosa Maestre, $2013,80]$.

A 23 de fevereiro de 1981, horas antes da tentativa do golpe militar neofranquista encabeçado pelo tenente-coronel Tejero Molina no Congresso de Deputados em Madrid, os filhos de José María Reales Carrasco apresentaram uma acusação à Audiência Provincial de Sevilha contra o realizador, a guionista Ana Vila e Pedro Gómez Clavijo, por escarnio à religião católica e ultraje público das cerimónias em honra da Virgem de Rocío (Del Río Sánchez e Espinosa Maestre, 2013, p. 82).

A 8 de abril, os acusados compareceram perante o juiz de instrução da 2. ${ }^{a}$ Secção da Audiência Provincial de Sevilha. Este ignorou a imputação apresentada pelos filhos de Reales Carrasco "de escarnio à religião católica" por considerar as cenas religiosas tratadas com respeito. Mais alegou que os factos apresentados podiam constituir matéria de delito de injúrias graves e indícios de criminalidade, competindo aos herdeiros de Reales o direito de apresentarem nova acusação, considerando que "Rocío los trata como hijos del jefe de una banda de asesinos" (2013, p. 83). Os incriminados ficaram em liberdade, obrigados a comparecer nos dias 1 e 15 de cada mês na respetiva secção judicial e ao pagamento de cinco milhões de pesetas de fiança. E a exibição do filme foi proibida nas províncias de Sevilha, Cádis e Huelva, mais ligadas à romaria.

Em junho de 1982, celebrou-se na 2. ${ }^{a}$ Secção da Audiência Provincial de Sevilha o juízo de instrução por "presumível delito de injúrias graves e calúnias" contra os autuados, envolvendo expectativas em diversos coletivos e uma ampla mediatização. Na sessão destinada a marcar a data do julgamento o juiz 
recusou-se a ouvir os 17 idosos de Almonte dispostos a certificar a veracidade dos crimes cometidos em 1936 pelo terratenente e falangista Reales Carrasco, relatados no filme por Pedro Gómez Clavijo. Negou-se igualmente a ouvir as declarações periciais de historiadores e cineastas, como Ian Gibson (Dublin, 1939) naturalizado espanhol em 1984 e Luis García Berlanga (Valencia, 1921 - Madrid, 2010). O processo constituiu-se como um campo de lutas entre o "direito à honra" e o direito à liberdade de expressão, com numerosos intelectuais, jornalistas e cidadãos anónimos a enviarem telegramas e petições de solidariedade com os acusados em defesa da liberdade de expressão. $\mathrm{O}$ juiz de instrução estabeleceu a pena de um ano de prisão menor a Fernando Vergara e a Ana Vila, quatro anos e dois meses a Pedro Gómez Clavijo, o pagamento de vinte mil pesetas de multa a cada um dos acusados, acrescido de dez milhões de pesetas de indemnização aos filhos de Reales Carrasco por prejuízos morais causados, bem como a eliminação dos fotogramas que o relacionavam com a repressão de 1936 em Almonte. Fernando Vergara assumiu todas as responsabilidades perante o juiz de instrução e Ana Vila e Pedro Gómez Clavijo tiveram de mentir para serem ilibados, a primeira delegando as responsabilidades no realizador e o segundo alegando desconhecer que a entrevista seria utilizada no filme. Pedro Clavijo, então com 73 anos de idade, protagonizou o momento mais doloroso da sessão ao ser obrigado a declarar que a participação no filme não fora voluntária, conduzindo o advogado de defesa a afirmar:

[...] Aquí se está enjuiciando, no a Pedro sino a la fuente oral de la historia, aunque me temo que a partir de ahora esos vecinos de Almonte van contar menos cosas que saben por la misma razón que Pedro Gómez ha enmudecido: el miedo que le ha hecho negar su propia imagen. ${ }^{48}$

A 21 de junho de 1982, a Audiência Provincial de Sevilha proferiu a sentença de dois meses e um dia de prisão maior a Fernando Ruiz Vergara, acrescida da multa de cinquenta mil pesetas e da indemnização de dez milhões de pesetas no conceito de responsabilidade civil por injúrias graves contra José Maria Reales Carrasco. O realizador recorreu da sentença ao Supremo Tribunal de Sevilha. A 3 de fevereiro de 1984 a sessão no Supremo foi presidida pelo magistrado Luis Vivas Marzal, entusiasta defensor do regime franquista. O juiz classificou o documental como um "libelo indecente" e ignorou o crime massivo que a película desvendava "por imposible demonstración". A eliminação

48 El Correo de Andalucía de 17 de junho de 1982, citado em (Del Río Sánchez e Espinosa Maestre, 2013, p. 85). 
dos fotogramas que relacionavam Reales Carrasco com a repressão de 1936 foi então justificada nos seguintes termos:

[...] Pronto aflora una inoportuna e infeliz recordación de episodios sucedidos antes y después del 18 de julio, en que se encarnece a uno de los bandos contendientes [...] es indispensable inhumar y olvidar si se quiere que los sobrevivientes y las generaciones posteriores a la contienda, convivan pacífica, armónica y conciliadamente, no siendo atinado avivar los rescoldos de esa lucha para despertar rencores, odios y resentimientos adormecidos por el paso del tiempo, sin que lo dicho obste a que relatos rigurosamente históricos, imparciales y no destinados al común de la gente, hagan honor al adagio De omnibus aut veritas aut nihil "O la verdad o nada" [...] [Espinosa Maestre, 2009, p. 53].

Fernando Ruiz Vergara foi condenado como autor "de un delito de injurias graves, hechas con publicidad difundida por cinematógrafo, a las penas de dos meses y un día de arresto mayor y multa de 50000 ptas" (RJ 1984/716, Sentencia Tribunal Supremo. Sala de lo criminal. 3 de febrero de 1984), acrescida da indemnização de dez milhões de pesetas que os filhos de Reales se comprometeram a doar à Hermandad Matriz de Rocío. O realizador não chegou a entrar na prisão mas a sentença destruiu-lhe a vida pessoal e profissional, condenando-o ao exílio voluntário em Portugal.

Em 2005 Fernando Vergara vivia em Barão de São Miguel (Algarve) repleto de memórias e de novos projetos. A infância e a juventude foram vividas em Huelva, com a miséria e a repressão do pós-guerra como pano de fundo. As injustiças sociais alimentaram-lhe um sentimento de revolta, expresso em rebeldia e na incessante procura da verdade. O sonho de estudar Belas Artes em Sevilha desfez-se no sistema de ensino franquista, sem o impedir de expressar pelas artes a sua visão do mundo. Ao longo de um percurso pejado de inevitabilidades desenvolveu diversas atividades para sobreviver, primeiro em Barcelona, depois Bruxelas e Alemanha junto de comunidades de emigrantes económicos e de exilados políticos espanhóis. As experiências acumuladas moldaram uma inabalável consciência política, entrelaçada em relações solidárias e utopias que conduziram à descoberta do cinema como arma carregada de futuro. Em 1974 experienciou a Revolução de Abril, recordada como o acontecimento mais importante da sua vida, impossível de esquecer pelas emoções que despertou, ao confirmar que a Revolução era possível e teve o privilégio de a viver. Em 1975 organizou ciclos cinematográficos no Algarve e no Norte de Portugal para os compatriotas espanhóis, ciente de que a morte do ditador não terminara com a censura em Espanha. Em 1976 criou o Centro de Intervenção Cultural (CIC) com Francisco Madeira 
Luís, ${ }^{49}$ Vítor Silva e Ana Vila. Juntos geriram o cinema Stadium em Algés, criando ciclos temáticos e exposições de artes plásticas. Em maio de 1976 organizaram a I Mostra Internacional de Cinema de Intervenção no Pavilhão dos Congressos do antigo Casino do Estoril, patrocinada pela Junta de Turismo da Costa do Sol. Ao longo das atividades que desenvolveu, Vergara procurou dar resposta às suas inquietações, e a famosa romaria andaluza de Huelva fazia parte delas. Em 1977 chegou a Almonte com Ana Vila, sua companheira, o diretor de fotografia Vítor Silva e Francisco Madeira Luís, para iniciar a rodagem dos rituais religiosos, seguindo-se a pesquisa documental e a recolha de depoimentos de historiadores, antropólogos e participantes da romaria. As "memórias fracas" da Guerra Civil e da repressão franquista surgiram espontaneamente nas narrativas dos residentes de Almonte, quando inquiridos sobre esse período histórico. Rocío representou assim o somatório de todas as experiências e utopias do seu realizador, a quem a critica cinematográfica espanhola reconheceu como um dos representantes do novo cinema andaluz e vaticinou uma carreira prometedora.

O caso Rocío decorreu entre 1981 e 1984, quando supostamente teria sido superado o primeiro período da transição (1976-1981), o golpe militar neo-franquista de 1981 e Espanha entrava em plena democracia com as maiorias absolutas do PSOE (1982-1996). No entanto, a justiça espanhola manteve-se em consonância com o poder político, na defesa da honra dos responsáveis pela repressão franquista, decretando penas de prisão pelo exercício do direito à liberdade de expressão. Em 1985 o filme regressou às salas de cinema com o testemunho dos crimes de José Maria Reales Carrasco substituído por um fundo negro com a legenda: "Supresión por sentencia de la Sala Segunda del Tribunal Supremo del 03.04.1984". Posteriormente, a própria censura foi censurada com o corte da legenda, de forma a não ser possível identificar o rasto da sentença. Em 1986, numa data tão simbólica como os 50 anos do início da Guerra Civil, no Congresso dos Deputados, Felipe González afirmou não ser aquele o lugar "para se analisar as causas de um acontecimento da magnitude da guerra civil, nem para valorizar as consequências que dele derivaram" (Molinero, 2015, p. 327).

As políticas da memória não foram preocupação dos governos socialistas e a "política de olvido" foi seguida pelos governos do Partido Popular

49 Francisco Madeira Luís (1933) foi um dos fundadores da Livraria Opinião, juntamente com Orlando Neves, livraria de referência na década de 70 pelo lançamento de livros que causaram enorme afluência de publico e problemas com a polícia política (PIDE/DGS). Doou o espólio de cartazes e publicações à Universidade de Aveiro. Disponível em http://www.ua.pt/sbidm/ museu/PageText.aspx?id=11741 [consultado em 12-12-2017]. 
(1996-2004). O vazio ético provocado pela ausência de políticas de verdade e justiça contribuiu decisivamente para a emergência do movimento social de recuperação da memória histórica e dignificação dos vencidos da guerra. A força do movimento social veio justificar a aprovação da Ley de la Memoria Histórica em 2007, no governo socialista de José Luis Rodríguez Zapatero (neto de um oficial republicano executado pelos falangistas em Agosto de 1936), que foi veemente refutada pelo PP por recear o julgamento do regime franquista.

Em 2005, nas I Jornadas Memoria y Justicia: la represión en Huelva y en la Cuenca minera, Fernando Ruiz Vergara foi socialmente dignificado e reapareceu publicamente a convite de historiadores e antropólogos da Asociación Andaluza Memoria Histórica y Justicia. A exibição do filme anunciada pelos organizadores na versão integral conduziu a novos protestos da Hermandad del Rocío e da família Reales, obrigando à projeção da versão censurada por permanecer vigente a sentença (Espinosa Maestre, 2009, p. 54). As apresentações de Rocío em jornadas, congressos e ciclos cinematográficos, as inscrições em livros e catálogos e os estudos académicos desenvolvidos sobre o caso consideraram Rocío como um documentário pioneiro, metáfora histórica da transição espanhola.

\section{ALGUMAS CONCLUSÕES INCONCLUSIVAS}

As políticas da memória desenvolvidas pelos Estados ibéricos modificaram-se com o tempo, satisfazendo as reivindicações de partes significativas da sociedade, sempre enquadradas em contextos histórico-sociais concretos. O passado transformou-se assim em memória social depois de selecionado e reinterpretado segundo as sensibilidades culturais, as interrogações éticas e as conveniências políticas de cada momento. Nos casos apresentados, as políticas da memória e a justiça transicional, mesmo incompletas ou imperfeitas, apresentam-se como componentes fundamentais nos processos de transição das ditaduras para a democracia nas suas facetas de rutura revolucionária ou de "reconciliação".

Em Portugal, o regime democrático procedente da Revolução de Abril mudou profundamente a anterior elite política e saneou os funcionários do regime, ao contrário da transição espanhola pactuada em que a maioria dos políticos e funcionários da ditadura transitaram para a democracia arrastando com eles legados do passado inconciliáveis e a judicialização da política como prática continuada.

As penalizações aplicadas ao realizador José Elyseu num quadro institucional, a possibilidade de reparação no recurso ao poder judicial e o acordo 
encontrado entre as partes em virtude de um diálogo político possível, em consonância com os princípios constitucionais de liberdade de expressão, contrariaram profundamente a sentença judicial aplicada ao realizador Fernando Vergara, num quadro jurisdicional em que o direito de liberdade de expressão foi subtraído pelo "direito à honra" dos perpetradores, facto que acentuava a ausência de uma rutura moral e política com o passado franquista e as ambiguidades da ambicionada "reconciliação nacional".

As lutas pela memória são lutas políticas estreitamente relacionadas com a correlação de forças dominantes em cada momento histórico e com a capacidade reivindicativa de diferentes grupos sociopolíticos nas sociedades. As políticas da memória desenvolvidas em Portugal e Espanha na primeira década da transição não são coincidentes, mas os casos apresentados mostram que a receção dos meios de reprodução da memória conduziu a debates que os transformaram num campo de lutas. No caso português, a luta envolveu representantes dos mais variados sectores da sociedade (religiosos, militares, políticos e intelectuais) e trespassou largamente o âmbito específico da construção da memória da guerra colonial, situando-se no combate às políticas de "desgonçalvização" da comunicação social, que ameaçavam as conquistas da Revolução consagradas na Constituição de 1976. Os discursos produzidos mostraram claramente como as forças políticas e sociais da direita portuguesa substituíram os fantasmas da ditadura fascista pela "ditadura marxista", que encontrava no "gonçalvismo" a sua máxima expressão, numa alusão ao v Governo Provisório de Vasco Gonçalves (1975) que durou um mês e no qual a direita portuguesa não esteve representada. Os discursos de repúdio às políticas das "esquerdas socialistas" surgiram amalgamados nas narrativas sobre a guerra colonial, por estas abalarem o poder de instituições consideradas intocáveis na conjuntura pós-revolucionária. O debate sustentado na imprensa durante quatro meses acompanhou o ciclo político do IV Governo Constitucional, que sucumbiu à contestação generalizada das forças sociais e políticas que ainda resistiam à ascensão das políticas neoliberais de privatização dos meios de comunicação social, de destruição da Reforma Agrária e inversão das nacionalizações anteriormente verificadas em diversos sectores da economia portuguesa.

O silenciamento dos massacres em África e da repressão franquista encontram similitudes no apoio incondicional das hierarquias religiosa e militar às ditaduras de Salazar e Franco, bem como no encobrimento dos perpetradores dos respetivos regimes. Estes crimes fazem hoje parte da extensa lista de crimes contra a humanidade e transformaram-se num campo de lutas pela superação do passado e pelo direito à verdade e à justiça. As memórias destas guerras estão incorporadas nas sociedades, em grupos e 
pessoas que tentam resgatar delas algum sentido como experiência necessária à construção do futuro. Ao restabelecerem o equilíbrio temporal entre o passado e o presente, as memórias têm o poder de reorganizar o pensamento e orientar a ação para a mudança. As lutas pela memória são lutas pelo futuro que não terminam com o reconhecimento público dos resistentes antifascistas e anticolonialistas, nem no momento da reparação das vítimas, mas possibilitam às novas gerações o exercício do dever irrevogável de edificarem sociedades mais justas. $\mathrm{O}$ desconhecimento de passados pejados de atrocidades e violações dos direitos humanos propiciam a manutenção de sociedades intolerantes, de vencedores e vencidos, e ameaçam o futuro da democracia. Num tempo de desmemória e revisão da história, de perda de valores e direitos fundamentais que foram o cimento das sociedades democráticas, é necessário promover a verdade e a justiça e não a impunidade, o diálogo, e não a judicialização da política, porque quando não o fazemos o passado pode sempre ressurgir sob diversas formas, mesmo quando existem acordos para o silenciar.

\section{REFERÊNCIAS BIBLIOGRÁFICAS}

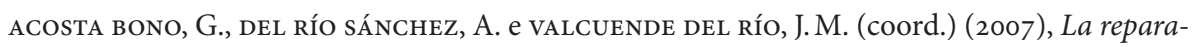
ción de la memoria histórica. Una perspectiva transversal desde las ciencias Sociales, Sevilha, Centro de Estudios Andaluces, Consejería de la Presidencia, Junta de Andalucía.

aguilar fernández, P. (2008), Políticas de la memoria, memorias de la política, Madrid, Alianza.

alvarado, A. (2013), "Un lobo con piel de cordero. La censura en el cine documental después de Franco". In Á. del Río Sánchez, F. Espinosa Maestre e J. L. Tirado (coord.), El caso Rocío. La historia de una película secuestrada por la transición, Seviha, Aconcágua, pp. 67-78.

Álvarez GonzÁlez, N. (2007), "La nueva censura (luces y sombras del Estado Liberal)”. Cuadernos Eletrónicos de Filosofia del Derecho, 15, Disponível em https://www.uv.es/cefd/15/ alvarez.pdf [consultado em 12-12-2017].

ARChILÈs, F., SANZ, J. (coord.) (2017), Cuarenta años y un día. Antes y después del 20-N, Valencia, PUV.

ARóstegui, J., GÁlvez, S. (coord.) (2010), Generaciones y memoria de la represión franquista. Un balance de los movimientos por la memoria, Valencia, Universidad de Valencia.

Brito, A.B., gonzález-enrique, C. e aguilar fernández, P. (coord.) (2004), Política da Memória. Verdade e Justiça na Transição para a Democracia, Lisboa, Imprensa de Ciências Sociais.

BRITO, A. B. (2013), “Justiça transicional e memória: exploração de perspetivas”. In A.C. Pinto (org.), A Sombra das Ditaduras: a Europa do Sul em Comparação, Lisboa, Imprensa de Ciências Sociais, pp. 41-64. 
CARdina, M. (2017), “A guerra colonial entre a memória e o esquecimento”. In C. Monteiro, K. Hilbert, P. Godinho (org.), Memória e Patrimônio: Diálogos entre Brasil e Portugal, Porto Alegre, EDIPUCRS, pp. 81-91.

Cardina, M., sena martins, B. (orgs.) (2018), As Voltas do Passado. A Guerra Colonial e as Lutas de Libertação, Lisboa, Tinta-da-China.

CARdoso, R. (2017), O 25 de Novembro e os Media Estatizados - Uma História por Contar, Lisboa, Caminho.

CASANova, J. (2004), Morir, matar, sobrevivir. La violencia en la dictadura de Franco, Barcelona, Crítica.

casanova, J. (coord.) (2015), “O castido no(s) pós guerra(s)”. In M. Loff, F. Piedade e L.C. Soutelo (coord.), Ditaduras e Revolução - Democracia e Políticas da Memória, Coimbra, Almedina, pp. 291-305.

CASANELlas, P. (2017), ¿Un país donde reina el orden? Represión, control social y resistencias al cambio antes y después de Franco". In F. Archilés e J. Sanz (coord.), Cuarenta años y un día. Antes y después del 2O-N, Valencia, Puv, pp. 97-123.

сово romero, F. (2004), Revolución campesina y contrarrevolución franquista en Andalucía. Conflictividad social, violencia política y represión franquista en el mundo rural andaluz, 1931-1950, Granada, Universidad de Granada.

CONAn, É., rousso, H. (1994), Vichy, un passé qui ne passe pas, Paris, Fayard.

Del río sánchez, A., ESPINOSA MAestre, F. (2013), "El caso Rocío y la transición. Persecusión, hostigamiento y caída de Fernando Ruiz Vergara”. In Á. Del Río Sánchez, F. Espinosa Maestre e J. L. Tirado (coord.), El Caso Rocío. La historia de una película secuestrada por la transición, Sevilha, Aconcágua, pp. 79-88.

espinosa maestre, F. (1996), La guerra civil en Huelva, Huelva, Diputación Provincial.

espinosa maestre, F. (2003), La columna de la muerte, El avance del ejército Franquista de Sevilla a Badajoz, Barcelona, Crítica.

ESPINOSA MAESTRE, F. (2006), Contra el olvido. Historia y memoria de la guerra civil, Barcelona, Crítica.

ESPINOSA MAESTRE, F. (2009), Callar al mensajero. La represión franquista, entre la libertad de información y el derecho al honor, Barcelona, Península.

espinOSA MAEstre, F. (2015), España 2001-2015. Lucha de historias, lucha de memorias, Sevilha, Aconcagua Libros.

FIRMO, M. (1978), Nas trevas da longa noite, Lisboa, Publicações Europa-América.

FRASER, R. (1979), Recuérdalo tú y recuérdalo a otros: historia oral de la guerra civil española, Barcelona, Crítica.

fentress, J., wickham, C. (1994), Memória Social, Lisboa, Teorema.

fuentes ARAgonés, J.F. (2008), “Transición”. In J. Fernández Sebastián e J.F. Fuentes (dir.), Diccionario político y social del siglo xx español, Madrid, Alianza Editorial, pp. 1173-1183.

gago, J.C.S. (coord.) (1979), Os Anos do Século. Poder Político e Comunicação Social, Lisboa, Sindicato de Actividades Cinematográficas.

GIBSON, I. (1971), La represión nacionalista de Granada en 1936 y la muerte de Federico García Lorca, Paris, Ruedo Ibérico.

halbwachs, M. (2006), A memória coletiva, São Paulo, Centauro.

HUMLEBAEK, C. (2013), "Atitudes partidárias e passado autoritário na democracia espanhola". In A.C. Pinto (org.), A Sombra das Ditaduras: a Europa do Sul em Comparação, Lisboa, Imprensa de Ciências Sociais, pp. 121-140. 
LE GOFF, J. (1989), “Memória”. Enciclopédia Einaudi, vol. 1, Memória-História, Lisboa, Imprensa Nacional Casa da Moeda, pp. 11-50.

LOFF, Manuel (2015), "Estado, democracia e memória: políticas públicas e batalhas pela memória da ditadura portuguesa (1974-2014)". In M. Loff, F. Piedade e L. C. Soutelo (coord.), Ditaduras e Revolução - Democracia e Políticas da Memória, Coimbra, Almedina, pp. 23-143.

MEsquita, M. (1994), “O Universo dos media entre 1974 e 1986”. In A. Reis (org.), Portugal 20 anos de Democracia, Lisboa, Círculo de Leitores.

Miguel, F. (1977), Uma Vida na Revolução, A Opinião.

moreno gómez, F. (1982), La República y la guerra civil en Córdoba, Córdova, Ayuntamiento de Córdoba.

MOLinero, C. (2015), "A herança do passado. O franquismo e a direita espanhola". In M. Loff, F. Piedade e L.C. Soutelo (coord.), Ditaduras e Revolução - Democracia e Políticas da Memória, Coimbra, Almedina, pp. 307-330.

ortner, S.B. (2019), "Practicing engaged anthropology". Anthropology of this Century, 25. Disponível em: http://aotcpress.com/articles/practicing-engaged-anthropology/ (consultado em 16-06-2019).

Pimentel, I. F. (2017), O Caso da PIDE/DGs. Foram Julgados os Principais Agentes da Ditadura Portuguesa?, Lisboa, Circulo de Leitores.

PINTO, A. C. (2013) "O passado autoritário e as democracias da Europa do Sul: uma introdução". In A.C. Pinto (org.), A Sombra das Ditaduras: a Europa do Sul em Comparação, Lisboa, Imprensa de Ciências Sociais, pp. 19-39.

PRESTON, P. (2011), El holocausto español: odio y exterminio en la Guerra Civil y después, Barcelona, Debate.

RAIMUndo, F. (2013), “Os partidos políticos e justiça de transição em Portugal: o caso da polícia política (1974-76)”. In A.C. Pinto (org.), A Sombra das Ditaduras: a Europa do Sul em Comparação, Lisboa, Imprensa de Ciências Sociais, pp. 87-119.

REIG TAPIA, A. (1984), Ideología e historia: sobre la represión franquista y la guerra civil, Madrid, Akal.

RosAs, F. (2015), "Ser e não ser: a revolução portuguesa de 74/75 no seu $4 .^{\circ}$ aniversário". In M. Loff, F. Piedade e L. C. Soutelo (coord.), Ditaduras e Revolução - Democracia e Políticas da Memória, Coimbra, Almedina, pp.195-205.

SOlÉ I SABATÉ, J., VILlARroya, J. (1989), La represión a la retaguarda de Catalunya (1936-1939), 2 vols., Barcelona, Publicaciones de l'Abadia de Montserrat.

soutelo, L. (2015), A memória pública do passado recente nas sociedades ibéricas. Revisionismo histórico e combates pela memória em finais do século $\mathrm{xx}$. Tese de doutoramento em História, Faculdade de Letras da Universidade do Porto.

SIMÕEs, D. (2013), Frontera y guerra civil Española. Dominación, resistencia y usos de la memoria, Badajoz, Diputación de Badajoz.

traverso, E (2012), O Passado, Modos de Usar. História, Memória e Política, Lisboa, Edições Unipop.

traverso, E. (2015), “Memórias europeias. Perspetivas emaranhadas". In M. Loff, F. Piedade e L.C. Soutelo (coord.), Ditaduras e Revolução - Democracia e Políticas da Memória, Coimbra, Almedina, pp. 405-426.

viÑAs, A., BLANCO, J. A. (2017), La guerra civil española, una visión bibliográfica, Madrid, Marcial Pons Historia. 
vinYes, R. (2011), Asalto a la memoria. Impunidades y reconciliaciones, símbolos y éticas, Barcelona, Los libros de lince.

YsÀs, P. (2015), "Memória e silêncio. A esquerda espanhola durante a transição". In M. Loff, F. Piedade e L.C. Soutelo (coord.), Ditaduras e Revolução - Democracia e Políticas da Memória, Coimbra, Almedina, pp. 331- 352.

Recebido a 05-02-2018. Aceite para publicação a 21-01-2020.

Simões, D. (2020), "Processos de construção da memória nas democracias ibéricas. Os casos Os Anos do Século (1979) e Rocío (1980)”. Análise Social, 235, LV (2.º), pp. 244-273.

Dulce Simões » masimoes@fcsh.unl.pt » Instituto de Etnomusicologia - Centro de Estudos em Música e Dança, Faculdade de Ciências Sociais e Humanas, Universidade Nova de Lisboa " Avenida Berna, 26 C 1069-061 Lisboa, Portugal » https://orcid.org/oooo-0001-8236-0234. 